\title{
特集 一血管透過の解析一
}

\section{綜 合 討 論}

林（座長・熊本大） 以上でお三方の応答が終 わりましたのでまとめに入りたいと思います。 最初の吉永さんの場合は，できればこれを定 量的な形で出したいという方法で mean lesion diameter と色素の抽出, それから radio active な物質を使っての counting という3つの方法 があるのですが，今特聞きした私個人の考学で はそれぞれ問題点があると思らのです。少なく ともこの中で一番网い得る方法として比較的容 易，かつ正確な成績を与えるのは抽出法じゃな いかと思らわけです。透過因子のスクリーニン グには mean lesion diameter 法, を使って, 一応笑験は可能でしょらが，それを精製すると か物質をはっきりしょらとする時には，やはり 抽出法と考皇ます，少し強いまとめ方で気にな るのですが，その点についてご質問・ご答弁い ただければありがたいと思います。

土屋（慶大）私，伺って扣りまして，抽出 法の昜合もある血管系の，たと放ば単位当たり ぞのくらい出ているかといら問題になります と, これは非常に問題じゃないかということ と，血管外組織との関係で透過した物質がさら に血管外で diffuse しやすいかどらか. その問 題も関係するものですから，笑際にはああいら 方法以外にないと思いますけど，臨床的に考光 る時やはり血管壁から透過したものがリンパに 入って，また元に戻る，その仕組がうまく行っ ている時はいくらものが透過しても問題はな い. 要するにたまるから edema とかその他の 2 次反応を造るということになるわけで，実際 に血管透過性を臨休面から考学る時に，やはり 何かもっとよい方法はないかと考光ました.

林今のは実験的な場合で人間が出てこない 話をしているわけですが，おっしゃるとうりだ ろらと思います。そうしますと色素に代わるよ らなものを使って，抽出することができればる っといいわけですね. 色素のいい点は目にすぐ
見えるといらことですね。これは何ものにも替 えがたい利点だろらと思います。ただ色素をそ のまますぐ形態学に持って行ければいいのです が，いろんな方法でチェックしても固定して標 本を作る過程で逃げてしまいます。だから色素 を固定可能にするような物質と結合させて使 う。しかも色素だけが抽出できるようなものが あれば，そのまま形態的追求も可能です。

鈴木（慶大）私も林先生があとめられたよ らな方法で，いつも活性物質を追っているわけ ですが，はたしてこれでいいかどらか。まあ逃 がしてしまらことはなかららといらところで 寸。それの先になりますと医学香のそれぞれの 専門の方に技渡しして研究していただくよりし ょらがないじゃないか，現在つかわれている色 素のかわりとなると今いい䠸光はありませ。 何か色素とこらいらものがつけばいいといらよ らに要求が具体的には，考光るにしてもつごう がよいのですが。そうすれ㧧たまたいろいろ 皆さんで相談すれば考党が出るかもしれませ ん.今の段階ではこらしたらいいじゃないかと いうように明解な扮答えはできません。

林 先生の抒っしゃる意制では，結諭的には 十分满足できないけれども，われわれは血管透 過性因子とか，ある程度の定量を見るには少な くとも mean lesion diameter で, 大ざっぱに方 向を見て，これは行けそらだといら場合に抽出 するということでしょらか。

鈴木 はい，私たちが気になるのは簡単でひ ろく網をはって活性物質をにがさない方法はど れかといらことになります。活性物質がある程 度純粋になってきた，その透過性の元進機啃の 解析となってくると，ちょっと僕たちには乎に 扣えないといら気をるって扣話しをらかがって ました。

林さっき吉永さんの話の中で radio active の物質は非常にいいけれども，面倒だとおっし 
やったのですが，その点, 吉永さんいかがです か。

吉永（熊本大）実際問題として方法は面倒 じゃないのです。．ただ，いやなるのを扱わねば ならず非常に用心してやらねばならんので，何 んとなく括っくうというところはあると思いま す。多少とも手間はかかっても僕の感じでは色 素のほうがやり易いと思います。

林さっきの括話では色素と抽出と radio active の比較がありました。感度からいうと radio active の湾らがいいですね。

吉永 絶対いいと思います。

林そらいうょうな感度を要求する実験の場 合には, いやでも radio active を使らというこ とになるわけですね。 しかし奏際問題としてそ らいうことはあまりないでしょう。

吉永 私は色素のほうを使っております。た だ非常に弱い透過穴進，たとえば遅延型アレル ギー現象のそれには，radio isotopeがよく用い られています。

林 それがもし非常にまれであれば，濃度曲 線を取るとかいう形で解決できることではあり ますね. 影山先生いかがでしょうか.

影山（慶大）それに関しては別に 異論はあ りません。さっき土屋さんの質問の中で，これ は当然出る質問だと思いますけれども，臨作の 先生に考えてもらいたいと思らのは, 要するに 透過暴常という問題と retention の問題が同時 にあると思うのです。われわれがある場所に， 滲出物が多いといらことは，差し引き勘定とし て多いという静实が示されているものと考充ま す. 下から逃げるものと，上から出るものの差 をはっきり出せと言われても困るといら感じが します。 それから marker の問題ですけれども 場合，目的によって方法を選んでいただいてよ いのでありまして，吉永さんの言われるように 色素のレベルでやれるのだったら結構じゃない ですか.ささらに詳しいのが必要ならば，別の方 法を考えるといらことでいいのじゃないでしょ らか。

林 次に渡辺さんの報告に入りたいと思いま すが，色素とか radio active とかいった方法で
行って，物質とか透過の現象が起こった時にど この場から出るか，どらいうふらに広がって行 くかということは，逆にその物質の特徽を決め て行くのにも非常に大切だろらと思います．普 通われわれ皮䖉などで寒験していると，透過は ほとんどjunction に起こるわけですけれども， junction のほかに細胞を通しても起こっている かも知れないといら心配が残りましょう。非常 に重要な方向と考えます。渡辺さんの打仕事で は明らかにその心配がでているわけですが，こ の場合にはX線の direct な影響があったのか, あるいは肺血管の特殊性によるのか, そういう 問題も重要になってくると思います。吉永先生 はいろんな organ の血管の特徴をスライドで示 されたのですが，そらいうことの認識も実験を する場合に非常に大事じゃないかと考えられま す。そういう点で渡辺さん，いかがでしょう 加.

渡辺（慶大）ああいった現象が Lunge の血 管の 1 つの特色であるかどらかといらことです が，同じような現象は心葴の血管でも，心歲に radiation をかけてその時の血管透過性を見る と, その時も同じような電子顕微鏡像を M.Y. Khan* らが "American Journal of Pathology" に出して拉ります。ですから Lunge の血管に 特徵的ではないと思います。また Lunge の血 管でも， radiation ばかりでなく oxygen 濃度 の高い空気，あるいは ozon を吸入させるとい ったような状態でも似たような現象が起こって 来ます。この場合突き詰めて行きますと, 発表 の中でもちょっと言ったのですが, radiation の effect といらのはどらいうところにあるか考 えをすと，膜の lipid の代謝にかなり影響を及 ぼす。变とらく lipid hydro-peroxidation みた いなものが起きる。 Ozon なんかやった場合も そうだと思います。そういうことを通じて，あ あいら vesicle の transport とか vesicle のでき ることに影響を及ぼす。今 radiation の影響, その lipid hydro-peroxidation が起きる現象の 実験を行っている最归です。また，X線照射が

* Khan, M.Y. and Ohanian, M.: Am. J. Path., 74: 125, 1974. 
病変として特殊な透過性物質を作ってしまった のではないかという点ですが，この場合透過を check する marker として用いているのは, 自 己の免疫グロブリン（anti horseradish peroxidase) であり，後にこれと specific antigen (horseradish peroxidase) を作用させてその局在部 位を推察しているのですから，X線照射によっ てこのような特翼抗体ができたとか，免疫グロ ブリンが透過し易い物質に変ったとかいらこと は考えられません。

林今の挆話, カーボンは市販されて招りま すし，すぐ実験できるわけですね，光学顕微鏡 でもある程度見当がつく、そういうもののよさ があると思らのですが.

渡辺そういらことはありません。初期に血 管透過性を増したかどらかを見るには，カーボ ンなり放射性物質あるいは色絜の方が手速く便 利な点があると思います。事実, immunoglobulinなんかすぐに目に見えるわけじゃありませ ん、ただ出た後にどらいら経路をたどるか． edema といら現象に結びつく炎症の滲出物が ぞんな状態を取るかを見るには，私が言った方 法は異物を使わず，また組織をいろいろ変える ことなくもっとも自然に近い条件で観察できる 点でよいと思います。

影山今の林さんと渡辺君の討論を聞いて感 じましたことは，林さんは mediator の立場か ら一応ものを見て行かれるわけで，あまりひど くない刺激，つまり火傷の炎症といったレベル での打仕事で mediator の実験をされている. 今日出した肺の問題は, 何んでもいいからデ カイ障害を造ろうといら方法でやった実験で す。それで障害の程度というものがかなりひど いと思らのですね. ですから林さんのやられた ようなシステムの実験と同じようには行かない のですね。渡辺君が一番問題にし，私も一番問 題にしていることの一つは, 血管から出たもの がどうたまって，それが何を起こすかといら立 場の形態学であって, この「血管透過性研究 会」でも問題になる細菌による「炎症の慢性 化」の機序の詳解明のためで，局所にたまった 体液がどのように変わって行くのだろらかを，
形態学の上で見る必要があるから，その場合に は, 一番よからうということです。

林 むし同じ奏験をして,カーボンを使った 時と peroxidase を使った時に，たとえば血管 透過性でも結構です。そこで全く同じような成 績になるのか．非常に違った成績になるかがわ かると大変ありがたいのです。

影山 林さんはそれを知りたいでしょう。そ らいう興味を持った人が抒やりになるといい。

(笑) 研究者といらのは一応自分の angleを持 って拉りますら。㗇があったらやってみます が, 実はカーボンの処理といらのは mesenchyme に入って行くと別の処理機構が僛くと考兄られ ます。われわれは，血管から滲出し，局所にた まった血清蛋白がどういうらうな形で組織の細 胞に影響を与えているか。 それが炎症の慢性化 にどのようなかかわり合を持っているかが，大

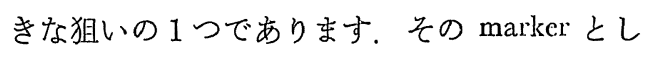
て，局所に対する翼物性の極めて少いものとし て，この方法を選んだわけです。

林 別に僕は研究の自由を束䄳与る氛持は全 然ありません，(笑) どちらがいいかどうか. この研究会として本当に peroxidase でないと絶 対いけないといらこともあるでしょら。そうい らことをはっきり認識するために必要じゃない かと思っているのです。

影山それはさっき言いましたよらに目的に よって違う，何を選んでもよろしいが，私ども の狙いは「炎症性水腫の疗続とその機槛」です から，どうしてもその動物の非にある蛋白の血 管外に出たものが，どのように経過するかを見 るためにこれをやったのであって，何んでもか んでも peroxidaseがよいと言っているわけでは ありません。彼はそこに狙いをつけて苫篎して やっているといらことだと思います。ですから カーボンはカーボンなりの便い道は十分あるで ありましょら。それはそれに楜したところで抒 使いになればよいことじゃないかと思います。

林またいつかじゃんじゃんやりましょう。

(笑)

服部（鹿児島市立病院）放射線をかけた場 合の末梢血管の透過性の問題は今ちょっと㧍っ 
しゃいましたが，肺だけでなく一番最初に世界 で霉われたのは1936年ですか，腸間膜を用いた 寒験で腸間膜の血管での透過性が増すと郝告さ れて怙ります。，その後は德島大学の怙仕事だっ たと思いますが，墨汁を使ってきれいな小腸粘 膜の契験がなされておりまず。だからほとんど 全身の末梢血管の透過性は増すのじゃないか と，現在言われていると思います。その透過性 を見るのに何を使ったらよいかという問題, 僕 は放射線科ですから RIを使ったほらが一番や り易いので，他の先生方とはちょっと立場が違 いますが，次回はこの問題を報告できるのじゃ ないかと思います。

林 僕は影山先生じゃないんですが，「何ん でもかんでも peroxidase，何んでもかんでも色 秦抽出」と言っているわけじゃないのです。で きれば 2 つ方法を使って比較し，それから少 なくとも結論を出すことが望ましいと思うので す。もっとも影山先生がイヤだと拐っしゃれば 别ですが…...

影山イヤだと言らわけじゃないのです。例 えばわれわれが血管の内膜が障書されて，それ からものが出る機情を研究するといらのであれ ば，林さんの拉っしゃるようにしてもかまわ ん、私どもの目的は別にあったからといら意味 でございます。

林 要するに希望はもら少し招招らかに…… (笑)

田中（九大）今の影山先生の括話と関連し て，扮㗇がありましたら fibrinogen の透過とい らことも見ていただきたいと思います。炎症の 慢性化ないしは渗出といらことを考える時，血 漿成分の中で fibrinogen の透過といらことが大 事と思いますし，それが組織内に deposit する 場合に括こる間葉系の赋活化ということが炎症 の慢性化の归では大事なことだと思います。

Albumin も大変大事だと思いますが, fibrinogen も大事と思いますので……

林今拐っしゃったことも，影山先生の拐っ しゃったことも本質的には非常によい方向に向 かっているわけですね，少なくとも流れている 物質を marker にするといらことは非常に重要
なことで，カーボンはそういう意味ではしょせ 儿便宜的な marker に過ぎません。今拈っしゃ ったように実際に流れている albumin とか免疫 globulin, fibrinogen とかいらものでの透過性の 問題に行かねばならんと思います。そういうる のがわかると同時に，それが関係している病変 の解析が始まっていることになるわけですか ら，扮っしゃると括りと思います。特に皮膚が 研究しやすいのですが，臨床的にはどこの蔵器 ということではなしに, 各藏器の体が透過性の 問題なので，そういう問題は矢吹さんから报話 もあったのですが，われわれがやっている実験 病理学的な方法と違ってはるかに難しく, 非常 にご笘学が多いと思います。そういう点で知吹 さんの扣話の中でご質問ありませんか．

藤井（德島大）ヒッツの方法で蛋白質の動 態を扣調べになって，血管透過性を推测して特 られると思うのですが，われわれ生化学の立場 から考えますと albumin の turn over といら のは，たとえば ACTH， cortison で非常に動い ているのじゃないかと思らのです。ですからそ らいうところをどうやって，どの程度考えたら いいのでしょらか.

矢吹（東邦大）ご質問をもら 1 回……

藤井 ストレスとかそらいら形で脾臟中の $\mathrm{ACTH}$ はしょっちゅう動いているわけです。 $\mathrm{ACTH}$ がたくさん出てきますと albumin の turn over は速くなってきます。例えば尿中の 血清のバランスを怙測りになっていただけれ ば，あそこの辺にどのくらいたまっているか， 減っているのかわかると思いますけど，その点 どらいららうに技考光になって执られますか。

矢吹 血中消失曲線を示す式怕，先程沶示し しましたように, intravascular compartment extravascular non-metabolic comportment 䦽よ び extravascular metabolic compartment の間 の albumin の交流として表わしてあります. したがって albumin の turn over に対する hormon の影響も当然計算されて打ります。

林 時間がまいりましたが，今は蛋白透過を 中心としていますが，将来は白血球，リンパ球， monocyte とかいった細胞の透過が蛋白透過と 
どう関係しているかといったようなことが問題 になるでしょう。また出る場所がそれぞれ違い ます，その場合にも定量的に知る方法とか，や はり同じような問題が起こってくると思いま す.

影山 いろいろ大㐓な問題がありましたが， 私きょらのシンポジウムを聞いて括りまして林 さんに感謝したいのは，去年のこの会で血管透 過の問題をもら少し掘り下げて考えてみたらど らか。その第 1 には方法論から見たらどうかと いらことをかなり強く提案しまして，林さんも 同調されて 3 つの立場から見て行くことになり ました，第 1 は量的条件の問題. 第 2 は marker の問題, ことに体液の exudation の問題をどう 見るか. 第 3 は非常に複雑な臨床の関先生グル 一プの情報選択と整理の方法についても，苦し いけれどやらねばならないという3つの点でご ざいました。これはこのままで終わるわけでは ないのであって，基礎側の方に特に打願いした いことは，対象に選ぶ毛細血管の性状を十分認 識してほしいということです。京極さんの扣話 にありましたが，血管によってはかなり透過の 様子が違ってくるのです。同じ血管を使って別 の見方ができたらどらなるのか，ということも 次の課題にしてもらいたい.と言いまずのはご
存知のように，林さんのグループのやっていら つしゃるあれは，最も基本的な結合織の血管を うまく使っていらっしゃる，骨慖とかリンパ管 の血管というのは，血球が出入りできるところ であるし，全く週った機能形態です，督蔵や内 分泌蔵器の血管に至ってはかなり違っている。

したがってまずは結合織の血管あるいはそれ に準ずる血管にポイントを置いて，林さんが言 われたような血管透過のメカニズムが，ものの 性質によるのか量によるのかいろんな問題があ ると思います。すう1つ基本的に大牙なこと は，「血管透過性研究会」でやっている血管透 過の妄進ということは，どうやら私の印象では 病的な滲出を言っているよらな感じがします。 そこで鹿取さんの質問がありましたけど，いっ たい albumin がどの程度に出るかというところ が病的と正常域の限界と思いますので，その辺 にも進んで行ったら，病的な琴象から生里的な 透過の問題へアプローチでさるのじゃないかと いう，たくさんの考え方を教わったように思い ます。

林 ありがとうございました．今招っしゃっ ていただいたことが大体結論みたいになりまし

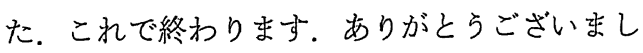
た。（拍手）

\section{月刊血液と脈管}

次号目次

第 6 巻第 3 号 (1975 年 3 月)
<特集 肝・胆・膵疾患の血液凝固異常 $>$

肝硬変之消化管出血

激症肝炎と DIC

閉塞性黄㾝の㠜固線溶異常..... 山本袿㚘・他

脺疾患と凝固線溶

肝胆道疾患における Hepaplatintest の意義・ 管原 篧・他 不戸迪郎・他 平山亮夫・他 三好秋哥・他 